\title{
The impact of institutions on the resources of foreign companies: the case of third party logistics service providers in Russia
}

\author{
Roger Moser, Christian Paul Jian Wei Kuklinski, Markus Weidmann ${ }^{* *}$
}

Emerging markets and transition economies challenge established business theories. In this paper, we conceptualise a framework incorporating the institution-and resource-based view to analyse how institutions impact the operations of western companies in a transition economy context: foreign third party logistics service providers (3PLs) in Russia. Our case study's findings center on the question of how institutions affect foreign 3PLs' local operations in Russia along six resource and six institutional dimensions. The findings assert the most challenging effects to occur in the areas of human resources, physical resources and organizational resources - and also suggest a new 'legal resource' in this particular context.

Schwellenländer und Übergangswirtschaften erfordern etablierte Geschäftstheorien. In diesem Artikel konzipieren wir einen Rahmen - unter Einbeziehung des institutionen- und des ressourcenbasierten Ansatzes - zur Analyse des Einflusses von Institutionen auf die Tätigkeiten westlicher Unternehmen im Kontext einer Transformationswirtschaft: Ausländische externe Logistikanbieter (3PL) in Russland. Unsere Fallstudienergebnisse fokussieren auf die Frage, wie Institutionen die lokalen Operationen der ausländischen 3PL in Russland beeinflussen, anhand von sechs ressourcenbezogenen und sechs institutionellen Dimensionen. Die Ergebnisse zeigen, dass die herausfordernsten Effekte in den Bereichen der personellen, physischen und organisatorischen Ressourcen auftreten - und legen eine zusätzliche "Legale Ressource" in diesem Kontext nahe.

Key words: institution-based view, logistics service providers, resource-based view, Russia, transition economies (JEL: L91, O43)

\footnotetext{
* Manuscript received: 5.2.13, accepted: 18.10 .13 (1 revisions)

** Dr. Roger Moser, Research Institute for International Management, University of St.Gallen. Main research interests: Emerging Markets, Transition Economies, Business Model Innovation, Trust and Network Development. E-mail: roger.moser@unisg.ch

Dr. Christian Paul Jian Wei Kuklinski, Visiting Researcher, China Europe International Business School, Stuttgart, Germany. Main research interests: Emerging Markets, Strategic Fit, Strategic Foresight, Business Development, Organizational Information Processing. E-mail: kchristian@ceibs.edu

Dr. Markus Weidmann, McKinsey \& Company, Munich, Germany. Main research interests: Supply Chain Management, Sourcing, Transition Economies. E-mail: markus_weidmann@mckinsey.com
} 


\section{Introduction}

Emerging markets as well as transition economies are characterized by rapid economic growth combined with the liberalisation and adoption of free-market principles (e.g. Hoskisson/Eden/Lau/Wright 2000). The increased saturation level of many industries in developed markets leave companies headquartered in these markets little choice but to enter emerging markets and transition economies. Yet, firms need to invest substantial efforts into understanding how they can benefit from these rapidly growing markets.

This is particularly challenging in transition economies since the institutional environment differs substantially from the relatively stable political, social and economic environments in developed markets (e.g. Jackson/Deeg 2008; Peng/ Wang/Jiang 2008). Managers of foreign firms cannot expect to conduct business operations in transition economies in the same manner as in their traditional home markets (Khanna/Palepu/Sinha 2005).

Researchers acknowledge that the unique social, political and economic characteristics of these markets are "challenging conventional wisdom" (Wright/Filatotchev/Hoskisson/Peng 2005:27) and that the unique institutional context of emerging markets and transition economies renders the sole application of wellestablished business theories and frameworks - rooted mainly in analyses of stable Western economies - as obsolete (e.g. Khanna/Palepu 1997; Narayanan/ Fahey 2005; Jackson/Deeg 2008). Established theories, research approaches and frameworks need to be adapted for these new markets to account for their dynamic institutional context (Wright et al. 2005).

Changes in the institutional environment within transition economies such as Russia are particularly substantial as centrally planned economies shift to freemarket economies (Banaia/Chanina/Teng 1999; Hoskisson et al. 2000). With the acknowledged relevance of institutions and the high interest in research on emerging markets, scholars have pushed the institutional perspective to "the leading edge of the strategy research agenda" (Wright et al. 2005:6). Although studies from other disciplines such as human resource management have shown that the "national institutional frameworks exert strong forces" on firms' local operations (Edwards/Colling/Ferner 2007:212), a profound research framework and explanation of 'how institutions matter' remains to be unveiled in various contexts (Meyer/Peng 2005; Wright et al. 2005; Jackson/Deeg 2008).

In this study, we explore how institutions affect the operations of foreign companies in a transition economy, namely third party logistics service providers (3PLs) in Russia. In particular, the paper draws on a specifically developed research framework to examine how the institutional context in a transition economy affects the local operations of foreign companies. We conceptualise our re- 
search framework based on the institution- and resource-based view, and apply the framework using case study methodology for this particular context - foreign 3PLs in Russia - to elicit how institutions affect the operations of western companies in a transition company. The developed framework intends to support a better understanding about how to assess and manage the dynamic institutional context in transition economies; the application to 3PLs in Russia allows for new insights about challenges associated with foreign firms' operations in this sector.

The upcoming section develops the framework drawing on both the institutionand the resource-based view. The next section depicts on 3PLs in Russia and presents the applied case study approach. The subsequent sections then introduce the study's results and discuss the findings. Afterwards, the paper closes with conclusions, identifies limitations and further research avenues.

\section{Theoretical background}

\subsection{Institutional perspective: economies and institutions in transition}

Institutions are, according to North (1990:3), "the rules of the game in a society or ... the humanly devised constraints that shape human interaction". They can be based either on written formal or unwritten informal rules and are transmitted by a wide variety of carriers ranging from rules, regulations and values to protocols, standards and objects of symbolic value (Scott 2008). Whereas changes in formal institutions can be quick since they are often paper-based, informal institutions are more reluctant to change since they are enmeshed in long lasting customs, traditions and codes of conduct (North 1990). Formal institutions thus arise from and are embedded in informal institutions and are consequently linked to culture and ideology (North 1990; Denzau/North 1994; Hofstede/Van Deusen; Mueller/Charles 2002; Scott 2008).

Concerning the transition process in Eastern European countries, researchers observed that, as a result of changing formal institutions, informal institutions at least temporarily increased in value because they offered a reliable guidance that the new laws and rules could not yet provide (Meyer/Peng 2005; Puffer/ McCarthy 2007). In general, an institutional transition is characterized by the replacement of a centrally planned regime through market-based transactions (Peng/Heath 1996); a transformation of a centrally planned to a market economy as can be observed in the former Soviet Union (Johanson 2008). A "deep structure (...) gradually gives way to new ones" resulting in fundamental changes of the formal and informal 'rules of the game' thus affecting organizations as the 'players of the game' (Peng 2003:278).

Planned economies such as the former Soviet Union made comprehensive use of central governance and set targets and actions for firms (Peng/Heath 1996). Be- 
fore the transition process, the typical firm in a planned economy was stateowned, governed by the planning regime and not primarily concerned about profitability or product quality (Peng/Heath 1996; Johanson 2008). Firms were oriented by quantitative plans and relied on government funds rather than focusing on efficiency and profitability (Peng/Heath 1996; Johanson 2004). Hence, firms were accustomed to receiving orders and specifications from a centralized regime and their profit orientation differed substantially - indicating a distinct firm behaviour (Peng/Heath 1996). While the central planning function (of an economy) diminishes and institutions are in transition, on the one hand a lack of adequate legal frameworks (formal constraints) can become prevalent; on the other hand a guidance by informal constraints is likely to arise. Consequently, those economies might become places of opportunism "and transaction costs are bound to be high" (Peng/Heath 1996:503).

Since (strategic) "choices are selected within and constrained by the institutional framework" (Peng/Heath 1996:500), such a transition affects not only individuals' decision making but also firms' operational and strategic behaviour. To a certain extent, this can result in an interactive character of some institutional developments; governmental decision-making processes might also be affected by both public and private entities involved (e.g. Edwards/Colling/Ferner 2007). Hoskisson et al. (2000) suggest that, as emerging economies evolve, first an institutional perspective is most relevant but needs to be gradually shifted to a resource-based perspective; some researchers also emphasize an integrative approach combining the two perspectives to be of crucial relevance and stipulate the applicability of resource-based advantages to ultimately depend on the institutional context (Oliver 1997; Brouthers/Brouthers/Werner 2008; Peng/Sun/ Pinkham/Chen 2009).

\subsection{Resource-based view}

Barney (1991) asserts that a firm's competitive advantage is based on a mix of resources that are valuable, rare, imperfectly imitable and non-substitutable. Since institutions often determine what is valuable, rare, imperfectly imitable, and non-substitutable in a specific country, a competitive advantage in one country might not represent a competitive advantage in another country due to distinct institutional contexts (Oliver 1997; Brouthers et al. 2008; Ingram/Silverman 2002; Bevan/Estrin/Meyer 2004; Peng et al. 2009). As a result of operating in distinct markets at the international level, firms are confronted with "questions of management ... in these varying contexts" (Brock/Siscowick 2007:354). Researchers also refer to this challenge as global integration versus local responsiveness arguing that corporate strategies concerning foreign subsidiaries have to account for an ambiguity: "They [subsidiaries] are pulled to achieve isomorphism with the local institutional environment, and they also face an imperative for consistency within the organization" (Rosenzweig/Singh 1991:340). 
Slack and Lewis (2001:16) argue that the strategy underlying a firm's local operations is "the total pattern of decisions which shape the long-term capabilities of any type of operation and their contribution to overall strategy, through the reconciliation of market requirements with operation's resources". In emerging markets and transition economies, companies often have to develop non-market -specific resources and capabilities normally provided by established institutions in other developed markets (Wan 2005). Companies have to account for what Khanna and Palepu (1997:63) labelled "institutional voids" such as the absence of adequate education systems or financial markets. In short: "Institutions directly determine what arrows a firm has in its quiver as it struggles to formulate and implement a specific strategy" (Ingram/Silverman 2002:20) - with the arrows symbolizing resources as the second perspective in the research framework.

\subsection{Research framework: the Institutions-Resources Matrix}

Only few concepts have been published framing analysis approaches and examining institutions in a particular setting (e.g. Khanna/Palepu 1997; Henisz/Zelner 2005; Khanna et al. 2005; Meyer/Nguyen 2005;). Henisz and Zelner (2005) elaborate a model of change analysing the institutional transition in emerging markets over a time period, whereas we focus on the institutional conditions during a limited timeframe and their impact on the strategic relevance of resources. Investigating varying institutional conditions within a country due to sub-national institutions on a local/regional level, Meyer and Nguyen (2005) develop an extensive model for foreign direct investments decisions while our research aims at the institutional context on a national level.

Offering a more industry-oriented approach for a comparison of institutions on country level, Khanna et al. (2005) conceptualize the institution-based view for emerging markets categorising five specific dimensions: (1) political and social systems, (2) openness, (3) product markets, (4) labour markets and (5) capital markets. The underlying logic is that companies need certain inputs for their production process, which they have to acquire at the local capital (5), labour (4) and product markets (3). At the same time, companies offer their products and services on the existing markets as outputs. These three market-oriented institutional contexts are subareas of the macro perspectives which account for the political and social systems (1) and the openness (2) of a country. According to Khanna et al. (2005), a common mistake in practice is to either focus only on the market-oriented or the macro institutional contexts while both substantially influence firms' operations. Since political and social change in transition economies such as Russia often occur at a different pace (Meyer/Peng 2005), our developed framework integrates Khanna et al.'s (2005) approach but separates the political and social systems into two dimensions. 
The second perspective of the research framework incorporates the resourcebased view following Grant's (1991) six tangible and intangible resources of a firm: (1) financial resources, (2) physical resources, (3) human resources, (4) technological resources, (5) organizational resources, and (6) reputation. The conceptual framework - the institutions-resources matrix - consequently integrates a combination of six institutional dimensions and six resource categories to support a structured analysis of how institutions matter in our focal research (Figure 1).

\section{Figure 1: Institutions-Resources Matrix}

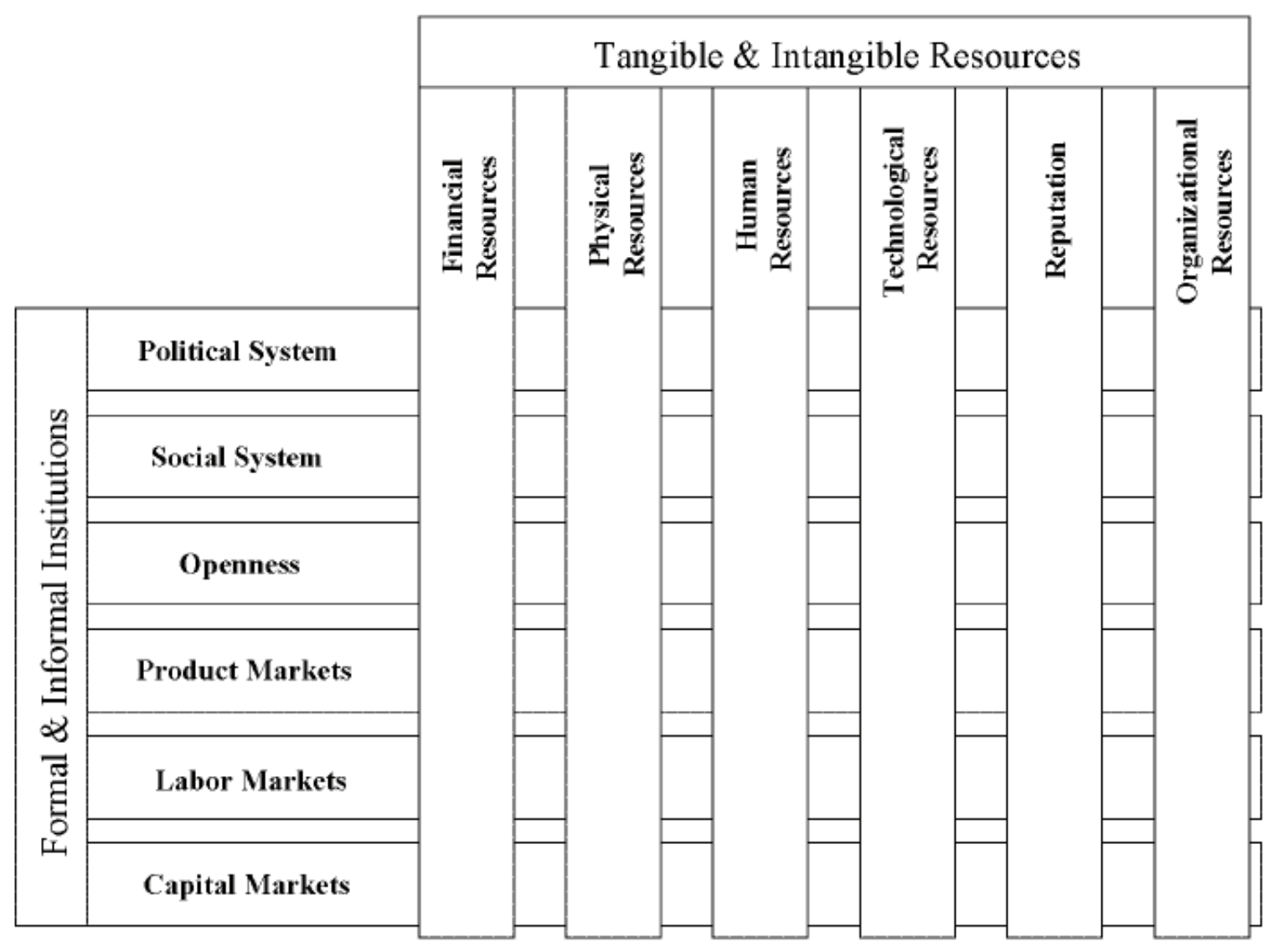

Figure 1 adapted from Grant (1991) and Khanna et al. (2005)

To further clarify the framework: in the context of product markets, intellectual property rights influence technological resources of a company. For example, policies concerning product imitation and piracy and their enforcement affect the attractiveness of local research and development operations (Khanna et al. 2005). Furthermore, acquiring information can become critical in the product market since "market research and advertising are in their infancy" - firms often struggle for reliable information about consumers (Khanna et al. 2005:67). Increasingly, information and knowledge take up a crucial role in both formal but also informal institutions: Without knowledge of, or access to, certain informal institutions (e.g. networks or relationships) it is more difficult to find a way around formal procedures in transition (Tonoyan 2010). 


\section{Methodology, field of research and case companies}

\subsection{Methodology}

We applied a case study methodology for three major reasons. First, case study methodology is particularly suited when conducting exploratory research in a real-life context with vague boundaries between context and a targeted phenomenon whose variables are not yet defined (Eisenhardt 1989; Meredith 1998; Yin 2003). The impact of institutions on the operations of companies has neither clearly defined variables nor a finite outcome. Second, case studies are particularly well-suited to answer how and why questions of current phenomena embedded in a complex context (Yin 2003). According to Yin (2003:2), "the distinctive need for case studies arises out of the desire to understand complex social phenomena." Third, case studies have been proven to be an effective method to deal with enormous amounts of data from distinct sources (Yin 2003). For the research project it was essential that the chosen method can explore both the formal institutions, with their laws and regulations, and the hardly visible informal institutions rooted in culture, norms and mindsets - thus requiring distinct information sources.

\subsection{Foreign third party logistics service providers in Russia}

Scholars perceive Eastern Europe as a unique laboratory setting due to the combination of high industrialization with rapid, radical transitions in social and economic aspects (Peng/Heath 1996; Meyer/Peng 2005). In general, such a process of transition is neither straightforward nor steady. Russia, in particular, is still more challenged by the transition process compared to many other Central and Eastern European countries of which some have already joined the European Union. Hence, opportunities for observing the influence of informal institutions are fairly high in Russia since transforming the informal institutions of a centrally-planned economy with a socialist ideology is a long process (Puffer 1995). Yet, informal institutions are less transparent compared to formal institutions, more difficult to identify and thus can also form a source of uncertainty especially for foreign firms - largely mirroring the current situation in Russia (Perotti/Gelfer 2001; Meyer/Nguyen 2005; Puffer/McCarthy 2007). In this context, 3PLs providers are of particular interest for research since distribution networks within transition economies are of even higher strategic relevance than in developed markets: 3PLs providers strongly support the geographical expansion of multinational enterprises (Prahalad/Lieberthal 1998; Khanna et al. 2005). This is also reflected in the fact that our case companies are among the first firms to enter the Russian market after the collapse of the former Soviet Union. 


\subsection{The 3PLs case companies}

Based on research in local media and industry publications, the following selection criteria allowed for an identification of 15 suitable 3PLs providers in Russia: foreign country of origin, international business operations, significant local operations and at least ten years of operational experience in Russia. The 15 companies were informed about the research project and, in case of their interest, named a contact person for the study. Those companies that expressed initial interest participated in subsequent meetings - these meetings allowed for a verification of the applied selection criteria for the four 3PLs from the initial set (Table 1).

\section{Table 1: Characteristics of the Four Case Companies}

\begin{tabular}{|c|c|c|c|c|}
\hline Company & A & B & $\mathrm{C}$ & $\mathrm{D}$ \\
\hline $\begin{array}{l}\text { Number of Em- } \\
\text { ployees in } \\
\text { Russia }\end{array}$ & $>1000$ & $>\mathbf{5 0 0}$ & $>\mathbf{5 0 0}$ & $<100$ \\
\hline Years in Russia & $>20$ & $>15$ & $>15$ & $>10$ \\
\hline $\begin{array}{l}\text { Logistics Ser- } \\
\text { vices offered }\end{array}$ & $\begin{array}{l}\text { Express deliv- } \\
\text { ery, freight, } \\
\text { value-added } \\
\text { services, cus- } \\
\text { toms clearance }\end{array}$ & $\begin{array}{l}\text { Contract logis- } \\
\text { tics, freight, } \\
\text { value-added } \\
\text { services, cus- } \\
\text { toms clearance }\end{array}$ & $\begin{array}{l}\text { Contract logis- } \\
\text { tics, freight, } \\
\text { value-added } \\
\text { services, cus- } \\
\text { toms clearance }\end{array}$ & $\begin{array}{c}\text { Freight, value- } \\
\text { added services, } \\
\text { airfreight, for- } \\
\text { warding }\end{array}$ \\
\hline $\begin{array}{l}\text { Number of } \\
\text { conducted } \\
\text { interviews }\end{array}$ & 10 & 6 & 5 & 3 \\
\hline
\end{tabular}

The case companies represent Russian subsidiaries of four major 3PLs with Western European backgrounds. All case companies have more than ten years of business experience in Russia, employ locally several dozens to more than 1.000 workers and provide services in the fields of transportation, contract logistics, value-added services, express deliveries and customs clearance using all modes of transport - apart from inland water ways - and offer almost a complete geographical coverage of Russia with branch offices also in remote regions.

\subsection{Data collection and analysis}

The data collection process included both desk and field research. We integrated archival data such as publications (e.g. newspapers, magazines, research on the Russian logistics market) and internal documents of all case companies in order to obtain an in-depth understanding of each 3PLs provider's operations and the relevant institutional context. Field research included also semi-structured interviews with key informants for each resource area from all four 3PLs. The interviewees were jointly selected with the respective contact person of each com- 
pany according to their position, years of experience in Russia and specialization within the company - covering each of the following six management areas with at least one interviewee per area in each of the four companies: General management, finance, marketing and sales, operations, human resources, and legal issues. In three instances, one interviewee responded to the questions for two areas due to joint organisational or structural responsibilities in the company; in one instance there was no officially assigned representative for one of the management areas.

The 52 open-ended starting questions in the interview guide were divided into six partly overlapping question sets (one for each management area) of which each set included 30 to 40 detailed questions. In total 24 interviews were conducted in the Moscow metropolitan area within four months with two interviewers each in order to avoid interviewer bias (Eisenhardt 1989). 16 of the interviewees were native Russians and eight were expatriate managers. The interviews lasted around 2 hours on average and were all recorded and transcribed.

More than 600 pages of transcribed interviews and additional documents and presentations provided by the case companies were analysed following the steps: categorisation, abstraction, comparison, dimensionalisation, integration and iteration (Spiggle 1994). During the categorisation process similar text passages were identified and linked to each other. The first level of categories is in line with the six resource types used in our research framework. Within these categories, sub-categories were identified, such as for human resources: labour law, retention, education and training, recruitment, compensation, and supervision. This analysis process was first performed within a single case and then across the four case companies. The identified patterns and structures were then abstracted into 'conceptual classes' such as "informal institutions replacing formal institutions" or "effects of Soviet heritage or Russian culture" (e.g. Spiggle 1994). The severity of the institutional impact on business success was then evaluated as part of the comparison and dimensionalisation. Finally, the findings were developed as part of the integration step, applying the results of the axial and selective coding (Corbin/Strauss 1990).

Company data, archives (e.g. newspapers, magazines) and existing research on the Russian logistics markets were compared with the interview results to diminish biases and unreliable information. Furthermore, the transcribed interview protocols were sent to the interviewees and returned together with their statements of consent. This procedure allowed for a validation of the verbal responses from the interviews through the transcribed statements. Afterwards each author separately matched patterns across several interviews for each case company. Finally, plausibility of the causal relationships of each identified pattern was discussed among the other authors to exclude non-identified variables for each case and across the four cases. 


\section{Findings along the Institutions-Resources Matrix}

The developed findings are presented along the research framework (Figure 1) and its six resource categories discussing the implications of the distinct institutional dimensions for the operations of Western companies in Russia, namely foreign 3PLs.

All interviewees highlighted human resources as a key resource for their operations in Russia. The analysis of the data revealed that all case companies experienced similar challenges in this resource category of Figure 1, especially regarding recruitment, qualification and retention management.

With respect to workforce qualification, especially management education was still in the early development stage. Nowadays graduates in Russia generally prefer to pursue a career in finance or consulting rather than logistics. Most interviewees admitted that they had difficulties in evaluating the qualification level of graduates and their distinct educational degrees. Furthermore, the interviewees stated to have little trust in many of the university diplomas, to have neither an overview of the relevant educational institutions nor their respective reputation and credibility. All case companies hence invested considerable efforts into application evaluations, in-house education and on-the-job training indicating an institutional void in the educational sector in context of the labour market.

The severity of this issue is intensified through another challenge, retention management, which is mainly affected by Russia's norms and values as part of the social system. The scarcity of well-qualified personnel was perceived to be particularly challenging due the high labour turnover rate: Across the sample, interviewees indicated a 10 to 25 percent annual turnover in the white-collar workforce. An expatriate general manager stated that he was at first surprised by many Russian Curriculum Vitae showing a new employer every one or two years. Moreover, the interviewees admitted that they struggle with the headhunting manoeuvres of mainly international competitors but pursued similar practices themselves.

The two human resource challenges induce not only a lack of transparency and a scarcity of well-qualified employees due to an institutional void in the educational system, but also a high workforce turnover rate due to institutional changes in the society's norms and values. In this respect, case companies perceived their headquarters' support in human resource management as insufficient. According to five of the interview partners, the insufficient headquarters' support was due to a missing understanding of their actual local requirements. Yet, the interviewed top managers of all four case companies saw this issue as something where they could make a difference locally. All four case companies pinpointed human resources as a key element of their operations in Russia and, in sum, we propose for human resources: 
Finding la (F1a): Western companies in Russia invest into in-house education and on-the-job training measures to close the institutional void in the education sector of the labour market.

Finding $1 b$ (F1b): Western companies in Russia face a dilemma by investing in retention management measures but in parallel recruiting personnel from their competitors due to the missing loyalty towards employers in the social system.

Regarding Financial resources, none of the examined 3PLs used any major local financing (apart from regular banking services). The results for this category of the Institutions-Resources Matrix (Figure 1) indicate that the procedure of capital acquisition seemed to pose neither a major advantage nor disadvantage for the case companies compared to their local competitors for two reasons. Firstly, most interviewees stated that, except for small local competitors, only few competitors had shortages of financial funds. Secondly, the case companies were also limited in the use of their own funds when linking this aspect to physical resources. The global strategy and the strategy in Russia of all four case companies was to hold as little own assets as possible. All interviewees considered it as especially risky to hold assets in Russia.

Moreover, Russian tax laws and their varying enforcement levels were a challenge for all four companies; the awareness of those varying circumstances may also play an important role. Two of the interviewed chief financial officers stated that mistakes in tax reports can be disastrous because business closures and frozen assets/accounts occur frequently in Russia due to mistakes in finance and accounting. Similarly, according to Russian law, transportation services for international imports and exports were not subject to Value Added Tax (VAT). However, none of the case companies could adhere to this law since reimbursing VAT for an international stretch of a transport proved not feasible in practice. The case 3PLs were compelled to charge their customers VAT for international transports or bear these additional costs themselves while many local competitors were able to bypass this issue. In sum, financial resources were hardly influenced by the institutional context of the local capital markets, but more so by the political perspective. We thus propose:

Finding $2 a$ (F2a): Western companies in Russia can operate independently of the financial markets except for taxation aspects.

Finding $2 b$ (F2b): Western companies in Russia adapt their financial resources primarily to the requirements of the political system.

Physical resources of the sample companies are mainly subject to long term leases or subcontracting. In contrast, domestic competitors used their large proprietary asset base as major sales argument in logistic outsourcing tenders. Some interviewees acknowledged that their company is challenged by providing value to large customers due to capacity problems in the overheated market. 
With respect to capacity issues, the interviewees of all case companies stated that the management of long-term co-operations with suppliers was especially difficult in the transportation sector. The case companies were not able to enforce contractual terms with subcontractors as they often shifted capacities for relatively small price premiums to other clients. All interviewees further emphasised that expectation for compliance with contracts in general is rather low. The management of subcontractors thus proved to be extremely difficult in practice in many cases requiring designated managers to supervise only one subcontractor in a particular region. These cost intensive selection and supervision processes encompass the considerably high risk level.

Another pattern identified across all four cases is that the examined 3PLs mainly served international clients with long-term, partially global contracts and longterm obligations for prices and capacities. This situation, in combination with short-term relations with local subcontractors and suppliers, results in unbalanced risks to the disadvantage of the examined 3PLs. Several of the interviewed senior executives expressed that this situation is a major concern for their operations. None of the examined 3PLs could rely on the services they demanded from their suppliers and thus were not able to transfer some of the risk to their subcontractors due to unreliable legal practices in Russia. At the same time, the case companies had to fulfil legally binding contracts with their global customers which were often legally enforced in other countries. Capacity guarantees in the contracts with their customers could therefore be classified as "bets" or "prayers" as labelled by two interviewees. Hence, for physical resources we propose:

Finding $3 a$ (F3a): Western companies in Russia apply extensive supplier management systems to overcome institutional voids in the legal environment of the political system as well as missing loyalty in business as part of the social system.

Finding $3 b$ (F3b): With their asset management approach, Western companies in Russia fail to balance the requirements of global contracts with international clients and the risks inclined by the weak formal political system in Russia.

Not all interviewees considered organisational resources - as another category of the framework in Figure 1 - to be of particularly high value for successful operations in Russia, but the interviewed operations managers of each case company stated that significant limitations exist compared to standard international transport procedures (e.g. to consolidate shipments for import and export). The interviewees also emphasised the importance of global key account management and access to industry experts at their headquarters. Moreover, some interviewees highlighted this set-up to be particularly valuable for their clients due to the difficulty of obtaining this knowledge locally and due to a more effi- 
cient claim and problem management through headquarters. The involvement of headquarters formed a major sales argument associated with a guarantee that prevails over the risks of enforcing local contracts for the (mostly international) clients. Yet, many interviewees stated that handling sales processes via global key accounts also had disadvantages. A major shortcoming was that agreements and contracts were often directly negotiated between the headquarters of their company and the client. According to the interviewees, involved managers from their headquarters were not able to sufficiently integrate the local context and especially unique legal requirements in Russia - ultimately resulting in higher costs or even lost projects. Several internal manuals regarding operational procedures that did not account for the specific context in Russia further underline these statements.

Overall, the interviewees perceived sales processes and partnership with Russian clients in general to be far more intense and time consuming than with international clients. The expatriate general manager of one company even stated that "the key to success in sales in Russia is spending time with the customer in the field". In addition, some interviewees highlighted that sales negotiations in Russia should be performed by native Russians due to the different nature of the negotiation process.

The operations of Russian and international companies are fairly distinct which is why the interviewees considered an in-depth understanding of any potential local client's relevant key-processes to be "vital" before signing a contract. Several examples of failed contracts due to substantial operational differences were provided during the interviews. For organisational resources, we thus propose:

Finding 4a (F4a): Western companies in Russia can leverage their international organisation structure to win international customers in Russia.

Finding $4 b$ (F4b): Western companies in Russia have to adapt their international organisation standards to attract local Russian customers.

According to the interviewees, reputation as a resource substantially contributes to their companies' sales success. A brand's esteem appears to be more important in express delivery than in freight, customs clearance or contract logistics. In the latter fields, the case companies mainly benefited from the general image of foreign high-quality service providers as stated by the interviewees. In this respect, the reputation of being an international service provider also significantly supported the sample companies' recruiting efforts. However, the interviewees covering this topic agreed that the reputation of their companies was not actively influenced by any of the analysed institutional contexts. Thus, although a firm's reputation plays a critical role for sales success, we propose for reputation as a resource:

Finding 5 (F5): Western companies in Russia do not experience any major influence on their reputation from any institutional context in Russia. 
Regarding the category technological resources in Figure 1: Except for the representative of one case company, the interviewees highlighted the value of technological resources but considered those neither to be a source of competitive advantage nor to be affected by any institutional context. The level of technology applied by their competitors was largely comparable and according to the interviewees, company internal documents and other archival data institutions hardly influenced this resource category. Nonetheless, the impact of institutions on technologies in, for example, the manufacturing industry, is expected to be higher compared to service providers as some interviewees stated. Based on the data retrieved from the case companies, we propose for technological resources:

Finding 6 (F6): Western companies in Russia do not experience any major influence on their technological resources from any institutional context in Russia.

On the contrary, interviewees perceived the legal context in Russia to be particularly relevant across all six resource categories. Asides from tax laws, the interviewees of all case companies emphasised the extremely complex Russian customs code to be particularly challenging for their operations. The interviewees stated that they often had to disregard operational efficiency in the customs context due to considerable differences in the actual degree of law enforcement. Good relations with local customs officials and a sound understanding of customs terminals in order to guarantee prompt processing took up a vital role for the case companies. For example, companies often re-routed freight to customs terminals with which they already had good experiences instead of directing freight to the nearest customs terminal.

Also the full-time employment of several lawyers (from two to five) in each except for the smallest case company underlined the role of the legal environment's particularities. The responsible interviewees of the smallest company also acknowledged that legal issues required special attention and they tried to accumulate expertise in this area but still relied on an external legal consultancy. When asked about this comparably large resource allocation, the general manager of one company stated that the Russian business unit was the only one in the Central and Eastern European region to have in-house lawyers, apart from headquarters, and that past experience had made this necessary.

The analysis of all four case companies revealed that the examined 3PLs regularly experienced legal issues of medium to high severity. Moreover, all interviewees observed a high divergence between the written law and the extent of its actual enforcement. Decision making in the legal field was described as "based on experience and contacts to authorities" rather than the formulation of legal codes. When asked about the protection of private property, one senior manager stated: “...if I build a warehouse, my property is not protected by any contract but by the actions and experience of the one lawyer assigned to it". Other inter- 
view partners stated that this level of experience, which also builds upon knowledge of informal - unofficially determined - specifications, had great influence on best practice operations. We thus propose:

Finding 7 (F7): Western companies in Russia invest in their own legal resources and adapt their operations to common practices due to weak formal institutions that are substituted by informal institutions across all institutional contexts in Russia.

\section{Discussion and conclusion}

Aside from the findings for the original six resource categories, an additional finding points out the crucial role of the legal environment's particularities across the examined operational aspects. On the contrary, the analysis revealed no significant institutional effects with respect to reputation (F5) and technological resources (F6). Nevertheless, reputation as a resource (F5) takes up an important role for the case companies; the assessment of technological resources (F6) is in line with Hitt et al. (2006) asserting the relevance of these resources for the internationalisation of service providers. Studies of other industries might come to different conclusions for these particular resources in the case of Russia because of the special business-to-business (B2B) character and a lower affinity of 3PLs with research and development (Hertz/Alfredsson 2003).

The strongest direct impact of the formal and informal institutional context in Russia was identified for human resources as a key success factor for local operations. This prioritisation is also emphasised in some management literature on Russia (e.g. Fey/Björkman 2001; Fey 2005; Karhunen 2008). The case companies are confronted with institutional voids in the Russian labour market because local institutions fail to provide an adequately qualified workforce (Fla). Although a number of higher education institutions for transportation and logistics existed in the former Soviet era - and some still exist today - their graduates apparently do not suit the requirements of the examined companies (Rodnikov 1994; Verbina/Chowdhury 2004; Panova 2008). In addition to a scarcity of well-qualified personnel, the Russian social system poses further challenges through high workforce turnover rates. In order to maintain global service operation levels, firms have to invest considerable efforts in retention management and simultaneously drive each other to increase their efforts when hiring their competitors' human resources. Western multinationals are therefore well advised to support their human resource development in Russia with specific training measures according to local requirements. Finding $1 b(F 1 b)$ suggests that these investments to close the institutional void are mostly non-exclusive for a single company. A simple solution to this problem does not exist but executives become increasingly aware that they are often a part of the problem due to hiring away each others' human resources - inducing higher costs also through salaries and fringe benefits as retention management measures. 
Apart from the issue of tax payments, financial resources of Western companies were identified to be largely unaffected by the institutional context $(F 2 a)$; while finding $2 b$ ( $F 2 b$ ) points out major disadvantages of a global 'low asset strategy' in a transition economy. A critical capability of business groups in emerging markets and transition economies is to accumulate sufficient financial funds (Khanna/Palepu 2000), but the examined 3PLs in Russia cannot make use of this advantage due to restricted available financial resources from their headquarters. "Importing capabilities ... of their parent companies" (Zaheer 1995:341) or raising capital on a local level to prevent shortage of financial funds may become a challenging aspect. The interviewees emphasised that financial resources take up a crucial role to create competitive advantage in Russia, although they stated that only few local competitors had to cope with shortages of funds. In addition, due to the varying enforcement levels of Russian laws, best accounting practices were hard to define and decisions were more often a matter of experience (e.g. Filo 2008).

According to finding $3 a$ ( $F 3 a$ ), weak formal institutions negatively impact the use of physical resources from subcontractors and suppliers. In line with existent findings in this field of research, the examined companies are frequently unable to enforce contractual terms with subcontractors (e.g. Johanson 2004). Limited power to enforce contracts and a relatively low availability of physical resources induce challenges for capacity management and increase the risk of not fulfilling contracts with international customers $(F 3 b)$. Since the protection of private property through the current legal institutions is still perceived as insufficient (e.g. Meyer/Peng 2005), a company's asset strategy in Russia is also affected by the degree of enforced private property protection. Possessing only a few specific assets can be advantageous due to lower risks and transaction costs (Meyer/Peng 2005; Gelbuda/Meyer/Delios 2008), whereas executives might need to rethink the 'one size fits all' global strategy since investing in physical assets in transition economies can also create a competitive edge.

Finding $4 a$ (F4a) and finding $4 b$ (F4b) pinpoint organisational challenges for a company that conducts operations in distinct institutional contexts. On the one hand, organizational resources that are of high value in developed markets (with a well-established formal institutional framework) might only be leveraged to a limited extent in other institutional environments. In line with Zaheer's (1995) assertion, the influence of firm-specific advantages such as organisational capabilities appears to be case-dependent. On the other hand, different institutional contexts challenge organisations to account for the ambiguity of global integration and local responsiveness (Rosenzweig/Singh 1991). Our findings for organisational resources are in line with this ambiguity: $F 4 a$ indicates a global integration approach for the subsidiaries to attract international clients in compliance with international standards in Russia, while $F 4 b$ states an adaptation according to local institutional conditions in order to attract domestic clients. For 
example, the possibilities to consolidate shipments are limited in Russia - a key element of economies of scale for 3PLs (Bolumole 2003; Hertz/Alfredsson 2003). Some reasons for this situation include customs regulations and their implementation (Bush 2002; Gill 2004), the split of the transportation market and the absence of necessary specialised facilities due to former central planning and geographic conditions (Rodnikov 1994). Since shipping represents a significant part of the transportation and logistics market, this can form a severe disadvantage especially for foreign companies - due to less familiarity with bypassing options regarding formal institutional constraints. However, whether foreign and domestic firms are confronted with this challenge at a comparable level in Russia remains to be unveiled. In this respect, Khanna et al. (2005) recommend managers to consider how their industry and their operations might differ between countries in order to better serve local customers. In the case of Russia, foreign firms are challenged by customising their organisational resources, not only to compete for local clients $(F 4 b)$ but also to remain attractive for international clients $(F 4 a)$.

Last but not least, finding 7 (F7) underlines that weak formal institutions across all institutional contexts induce Western companies to invest substantially in inhouse legal support and adapt their standard legal operations to common local procedures driven by specifically developed practices, gathered experiences and interpretations rather than by the written law. In line with Bevan et al. (2004), the interviewees observed a high divergence between the written law and its actual enforcement. This situation further strengthens the perception that as formal institutions change, informal institutions temporarily increase in value because they provide guidance which new laws and rules cannot offer yet (e.g. Meyer/Peng 2005; Puffer/McCarthy 2007). As a result, managers of Western companies in Russia need to closely monitor the legal environment and direct attention to gaps between the written and actually enforced law (Bevan et al. 2004). Finally, the study results emphasise that experiences of in-house legal personnel, as a 'legal resource', can contribute significantly to best-practice operations. The constant adaptation of Western companies' business model in Russia thus not only incorporates operational efficiency considerations or customer requirements but also draws fundamentally on legal considerations. The results hence indicate an underlying perspective - affecting other formal institutional dimensions - to be explicitly taken into account in Figure 1: legal environment. An integration of an additional legal resource dimension following the applied resource-based view (Grant 1991) appears suitable in this particular research context. At least, the role of legal aspects for the design and adaptation of business models is of critical relevance in the context of Russia. 


\section{Contribution, limitations and future research}

The study's findings contribute to a better understanding about the impact of institutions on the operations of Western companies in Russia as a transition economy, and the introduced framework allows for a systematic analysis of interrelations between institutions and firms' resources - its structured approach is particularly promising for further examinations in transition economies and emerging markets at large (e.g. cross country/industry analyses). The study's results offer insights for Western companies in Russia in general and for 3PLs and other primarily business-to-business driven service industries in particular.

Yet, a generalisation of the proposed interrelations between institutions and firms' resources is hardly defensible - especially when accounting for distinct industries and their differing institutional environments. Thus, it remains to be explored whether the findings are industry- or Russia-specific or might represent patterns to be found in other transition economies or emerging markets in general. Another limitation is the complex operationalisation of the institutional context, especially regarding informal institutions (Peng 2001; Meyer/Peng 2005). In addition, the interviewees' background has to be noted: 16 of 24 interview partners were native Russians who gathered substantial international experience as executives in different companies and countries, spent most of their life in Russia, were familiar to the institutional environment and had learnt to manage the institutional context's implications for businesses at an early stage.

The notably high relevance of human resources in transition economies and the strong influence of institutions make further examinations - in light of the presented findings - such as cross-analyses of more patterns in other industries/ emerging markets particularly fruitful research avenues. Furthermore, researchers should examine in more detail the critical role of additional legal advice in an environment of weak formal institutions - also integrating perspectives from, for example, transaction cost theory. In this respect, the underlying legal environment is also a promising focal point for researchers aiming at quantifying a "liability of foreignness" (Zaheer 1995:341). Hence, for transition economies such as Russia, the presented results and particularly the developed research framework are another essential step towards further investigating 'how institutions matter'.

\section{References}

Banaia, M./Chanina, M./Teng, B.-S. (1999): Russian managers' perceptions of prospective Russian-US joint ventures, in: International Business Review, 8, 17-37.

Barney, J. (1991): Firm Resources and Sustained Competitive Advantage, in: Journal of Management, 17, 1, 99-120.

Bevan, A./Estrin, S./Meyer, K.E. (2004): Foreign investment location and institutional development in transition economies, in: International Business Review, 13, 1, 43-64. 
Bolumole, Y.A. (2003): Evaluating the Supply Chain Role of Logistics Service Providers, in: The International Journal of Logistics Management, 14, 2, 93-107.

Brock, D.M./Siscowick, I.C. (2007): Global integration and local responsiveness in multinational subsidiaries: Some strategy, structure, and human resource contingencies, in: Asia Pacific Journal of Human Resources, 45, 3, 353-373.

Brouthers, K.D./Brouthers, L.E./Werner, S. (2008): Resource-Based Advantages in an International Context $\dagger$, in: Journal of Management, 34, 2, 189-217.

Bush, J. (2002, 21.01.2002): Importer beware, in: Business Eastern Europe - The Economist, 6.

Corbin, J./Strauss, A. (1990): Grounded Theory Research: Procedures, Canons, and Evaluative Criteria, in: Qualitative Sociology, 13, 1, 3-21.

Denzau, A.T./North, D.C. (1994): Shared Mental Models: Ideologies and Institutions, in: Kyklos, 47, 1, 3-31.

Edwards, T./Colling, T./Ferner,A. (2007): Conceptual approaches to the transfer of employment practices in multinational companies: an integrated approach, in: Human Resource Management Journal, 17, 3, 201-217.

Eisenhardt, K.M. (1989): Building Theories from Case Study Research, in: Academy of Management Review, 14, 4, 532-550.

Fey, C.F. (2005): Opening the black box of motivation: A cross-cultural comparison of Sweden and Russia, in: International Business Review, 14, 3, 345-367.

Fey, C.F./Björkman, I. (2001): The Effect of Human Resource Management Practices on MNC Subsidiary Performance in Russia, in: Journal of International Business Studies, $32,1,59-75$.

Filo, K. (2008): Managing cash in Russia: Best practice, in: Journal of Corporate Treasury Management, 2, 2, 160-167.

Gelbuda, M./Meyer, K.E./Delios, A. (2008): International business and institutional development in Central and Eastern Europe, in: Journal of International Management, 14, $1,1-11$.

Gill, P. (2004, 09.08.2004): Muddling through, in: Business Eastern Europe - The Economist, 3 .

Grant, R.M. (1991): The Resource-Based Theory of Competitive Advantage: Implications for Strategy Formulation, in: California Management Review, 33, 3, 114-135.

Henisz, W./Zelner, B. (2005): Legitimacy, Interest Group Pressures, and Change in Emergent Institutions: The Case of Foreign Investors and Host Country Governments, in: Academy of Management Review, 30, 2, 361-382.

Hertz, S./Alfredsson, M. (2003): Strategic development of third party logistics providers, in: Industrial Marketing Management, 32, 2, 139-149.

Hitt, M.A./Bierman, L./Uhlenbruck, K./Shimizu, K. (2006): The Importance of Resources in the Internationalization of Professional Service Firms: the good, the bad, and the ugly, in: Academy of Management Journal, 49, 6, 1137-1157. 
Hofstede, G./Van Deusen, C.A./Mueller, C.B./Charles, T.A. (2002): What Goals Do Business Leaders Pursue? A Study in Fifteen Countries, in: Journal of International Business Studies, 33, 4, 785-803.

Hoskisson, R.E./Eden, L./Lau, C.M./Wright, M. (2000): Strategy in Emerging Economies, in: Academy of Management Journal, 43, 3, 249-267.

Ingram, P./Silverman, B. (2002): Introduction, in: Ingram P./Silverman B. (eds.): The New Institutionalism in Strategic Management, Amsterdam: Elsevier, 1-30.

Jackson, G./Deeg, R. (2008): Comparing capitalisms: understanding institutional diversity and its implications for international business, in: Journal of International Business Studies, 39, 4, 540-561.

Johanson, M. (2004): Chains, holes, and links: Organisation of activities in supplier relationships in the Russian transition economy, in: Journal of Purchasing \& Supply Management, 10, 6, 233-245.

Johanson, M. (2008): Institutions, exchange and trust: A study of the Russian transition to a market economy, in: Journal of International Management, 14, 1, 46-64.

Karhunen, P. (2008): Managing international business operations in a changing institutional context: The case of the St.Petersburg hotel industry, in: Journal of International Management, 14, 1, 28-45.

Khanna, T./Palepu, K. (1997): Why Focused Strategies May Be Wrong for Emerging Markets, in: Harvard Business Review, 75, 4, 41-51.

Khanna, T./Palepu, K. (2000): The Future of Business Groups in Emerging Markets: LongRun Evidence from Chile, in: Academy of Management Journal, 43, 3, 268-285.

Khanna, T./Palepu, K.G./Sinha, J. (2005): Strategies That Fit Emerging Markets, in: Harvard Business Review, 83, 6, 63-76.

Meredith, J. (1998): Building operations management theory through case and field research, in: Journal of Operations Management, 16, 4, 441-454.

Meyer, K.E./Nguyen, H.V. (2005): Foreign Investment Strategies and Sub-national Institutions in Emerging Markets: Evidence from Vietnam, in: Journal of Management Studies, 42, 1, 63-93.

Meyer, K.E./Peng, M.W. (2005): Probing theoretically into Central and Eastern Europe: transactions, resources, and institutions, in: Journal of International Business Studies, $36,6,600-621$.

Narayanan, V.K./Fahey, L. (2005): The Relevance of the Institutional Underpinnings of Porter's Five Forces Framework to Emerging Economies: An Epistemological Analysis, in: Journal of Management Studies, 42, 1, 207-223.

North, D.C. (1990): Institutions, Institutional Change and Economic Performance. Cambridge: Cambridge University Press.

Oliver, C. (1997): Sustainable competitive advantage: Combining institutional and resourcebased views, in: Strategic Management Journal, 18, 9, 697-713.

Panova, A. (2008): Governance Structures and Decision Making in Russian Higher Education Institutions, in: Problems of Economic Transition, 50, 10, 65-82. 
Peng, M.W. (2001): The resource-based view and international business, in: Journal of Management, 27, 6, 803-829.

Peng, M.W. (2003): Institutional Transitions and Strategic Choices, in: Academy of Management Review, 23, 2, 275-296.

Peng, M.W./Heath, P.S. (1996): The Growth of the Firm in Planned Economies in Transition: Institutions, Organizations, and Strategic Choice, in: Academy of Management Review, 21, 2, 492-528.

Peng, M.W./Wang, D.Y./Jiang, Y. (2008): An institution-based view of international business strategy: a focus on emerging economies, in: Journal of international Business Studies, $39,5,920-936$.

Peng, M.W./Sun, S.L./Pinkham, B./Chen, H. (2009): The Institution-Based View as a Third Leg for a Strategy Tripod, in: Academy of Management Perspectives, 23, 3, 63-81.

Perotti, E.C./Gelfer, S. (2001): Red barons or robber barons? Governance and investment in Russian financial-industrial groups, in: European Economic Review, 45, 9, 1601-1617.

Prahalad, C.K./Lieberthal, K. (1998): The End of Corporate Imperialism, in: Harvard Business Review, 76, 4, 68-79.

Puffer, S.M. (1995): Shedding the Legacy of the Red Executive: Leadership in Russian Enterprises, in: International Business Review, 4, 157-176.

Puffer, S.M./McCarthy, D.J. (2007): Can Russia's state-managed, network capitalism be competitive? Institutional pull versus institutional push, in: Journal of World Business, 42, $1,1-13$.

Rodnikov, A.N. (1994): Logistics in Command and Mixed Economies: The Russian Experience, in: International Journal of Physical Distribution \& Logistics Management, 24, 2, 4-14.

Rosenzweig, P.M./Singh, J.V. (1991): Organizational Environments and the Multinational Enterprise, in: Academy of Management Review, 26, 2, 340-361.

Scott, R.W. (2008): Institutions and Organizations - Ideas and Interests. Thousand Oaks: Sage Publications.

Slack, N./Lewis, M. (2001): Operations Strategy, in: FT European ed. London, Prentice Hall: Financial Times.

Spiggle, S. (1994): Analysis and Interpretation of Qualitative Data in Consumer Research, in: Journal of Consumer Research, 21, 3, 491-503.

Tonoyan, V./Strohmeyer, R./Habib, M./Perlitz, M. (2010): Corruption and Entrepreneurship: How Formal and Informal Institutions shape Firm Behaviour in Transition and Mature Market Economies, in: Entrepreneurship Theory and Practice, 34, 5, 803-831.

Verbina, I./Chowdhury, A. (2004): What determines public education expenditures in Russia?, in: Economics of Transition, 12, 3, 489-508.

Wan, W.P. (2005): Country Resource Environments, Firm Capabilities, and Corporate Diversification Strategies, in: Journal of Management Studies, 42, 1, 161-182.

Wright, M./Filatotchev, I./Hoskisson, R.E./Peng, M.W. (2005): Strategy Research in Emerging Economies: Challenging the Conventional Wisdom, in: Journal of Management Studies, 42, 1, 1-33. 
326 Moser, Kuklinski, Weidmann; The impact of institutions on the resources of foreign companies

Yin, R. (2003): Case Study research: design and methods. London: Sage Publications.

Zaheer, S. (1995): Overcoming the Liability of Foreignness, in: Academy of Management Journal, 38, 2, 341-363. 